\title{
SISTEM PENDUKUNG KEPUTUSAN SELEKSI PENERIMAAN BANTUAN TERNAK SAPI MENGGUNAKAN METODE PROFILE MATCHING PADA DESA BUNTULIA UTARA KABUPATEN POHUWATO
}

\author{
Anasi $^{1}$, Azwar ${ }^{1}$ \\ ${ }^{1}$ Universitas Ichsan Gorontalo \\ E-mail: anasunisan89@gmail.com
}

\begin{abstract}
Abstrak: Usaha ternak sapi merupakan usaha yang memiliki potensi besar khususnya di Desa Buntulia Utara Kabupaten Pohuwato Provinsi Gorontalo. Program bantuan yang disalurkan pemerintah saat ini sangatlah bermanfaat khususnya terhadap masayarakat menengah kebawah khususnya bantuan ternak sapi. Namun dalam pelakasanaannya terkadang bantuan yang diberikan oleh pemerintah belum optimal. Hal ini dikarenakan penyaluran bantuan ternak sapi belum mengacu pada kriteria yang ada. Dimana proses penyebaran tidak mempertimbangkan faktor wilayah, pakan dan kriteria lainnya. Sehingga banyak ternak yang tidak dapat berkembang biak dengan baik. Diharapkan aplikasi ini dapat bermanfaat bagi pihak yang terkait dan dapat membantu pihak pengambil keputusan dalam menentukan penerima yang layak mendapatkan bantuan.
\end{abstract}

Kata Kunci: Bantuan, Kelompok, Penerima, Sapi, Ternak

\section{PENDAHULUAN}

\section{A. Latar Belakang}

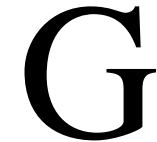

orontalo memiliki peluang yang besar dalam upaya pengembangan usaha ternak sapi karena didukung oleh keadaan lingkungan serta lahan yang luas khususnya di Desa Buntulia Utara Kabupaten Pohuwato. Ternak sapi mempunyai prospek dan potensi pasar yang cerah. Usaha ternak sapi merupakan usaha yang memiliki potensi besar khususnya pada bulan-bulan mendekati Idul Adha.

Kebutuhan akan sapi kurban sangatlah tinggi sehingga akan memberikan dampak yang besar bagi para peternak. Untuk mendukung pengembangan usaha budidaya ternak sapi, Pemerintah sangatlah berperang penting dalam pengadaan atau pemberian bantuan sapi kepada peternak. untuk mencapai harapan pemerintah maka kontrol dan manajemen pengelolaan perlu dilakukan dengan baik. Evaluasi secara bertahap kepada peternak sangat penting dilakukan untuk mengetahui tingkat pencapaian tujuan, karena seringkali program seperti ini mengalami kegagalan dalam pencapaian tujuan. Kegagalan biasanya terjadi karena pemberian bantuan sapi ternak tidak sesuai dengan sasaran. (Kades Buntulia Utara. 2018).

Berdasarkan latar belakang di atas, maka penyusun melakukan suatu penelitian tentang pendukung keputusan yang dapat diterapkan pada Kantor Desa Buntulia Utara. Selanjutnya penelitian ini diberi judul "Sistem Pendukung Keputusan Seleksi Penerima 
Bantuan Ternak Sapi Menggunakan Metode Profile Matching Pada Desa Buntulia Utara".

Adapun bahasa pemrograman yang digunakan adalah PHP dengan MYSQL sebagai databasenya. Semoga dengan adanya sistem ini akan memberikan hasil yang objektif sesuai yang diharapkan masyarakat. Sehingga dapat memberikan solusi dalam pemberian bantuan ternak sapi khususnya di Desa Buntulia Utara.

\section{B. Rumusan Masalah}

Berdasarkan latar belakang masalah diatas, maka dapat dirumuskan permasalahan yaitu :

1. Bagaimana cara merekayasa Aplikasi Sistem Pendukung Keputusan Seleksi Penerima Bantuan Ternak Sapi dengan menggunakan metode Profile Matching Pada Desa Buntulia Utara?

2. Apakah Sistem Pendukung Keputusan Seleksi Penerima Bantuan Ternak Sapi dengan menggunakan metode Profile Matching yang direkayasa dapat diimplementasikan pada Kantor Desa Buntulia Utara?

\section{Tujuan Penelitian}

Adapun tujuan dari penelitian ini adalah :

1. Untuk mengetahui cara merekayasa Sistem Pendukung Keputusan Seleksi Penerima Bantuan Ternak Sapi dengan menggunakan metode Profile Matching Pada Kantor Desa Buntulia Utara.

2. Sistem pendukung keputusan Seleksi Penerima Bantuan Ternak Sapi menggunakan metode profile matching yang direkayasa dapat diimplementasikan pada Kantor Desa Buntulia Utara.

\section{METODE PENELITIAN}

\section{A. Objek Penelitian}

Objek dari penelitian ini adalah "Sistem Pendukung Keputusan Seleksi Penerima Bantuan Ternak Sapi Menggunakan Metode Profile Matching Pada Desa Buntulia Utara" penelitian ini bertempat di Desa Buntulia Utara Kabupaten Pohuwato Provinsi Gorontalo.

\section{B. Metode Penelitian}

Metode Profile Matching atau pencocokan profil adalah metode yang sering digunakan sebagai mekanisme dalam pengambilan keputusan dengan mengasumsikan bahwa terdapat tingkat variabel prediktor yang ideal yang harus dipenuhi oleh subyek yang diteliti, bukannya tingkat minimal yang harus dipenuhi atau dilewati (Kusrini, 2007). Dalam proses Profile Matching secara garis besar merupakan proses membandingkan antara nilai data aktual dari suatu profile yang akan dinilai dengan nilai profil yang diharapkan, sehingga dapat diketahui perbedaan kompetensinya (disebut juga gap), semakin kecil gap yang dihasilkan maka bobot nilainya semakin besar yang berarti memiliki peluang lebih besar untuk direkomendasikan sebagai calon Penerima bantuan sapi ternak

Berikut adalah beberapa tahapan dan perumusan perhitungan dengan metode Profile Matching (Kusrini, 2007): 
1. Pembobotan

Pada tahap ini, akan ditentukan bobot nilai masing-masing aspek dengan menggunakan bobot nilai yang telah ditentukan bagi masing-masing aspek itu sendiri. Adapun inputan dari proses pembobotan ini adalah selisih dari profil karyawan dan profil jabatan. Dalam penentuan peringkat pada aspek kapasitas intelektual, sikap kerja dan perilaku untuk jabatan yang sama pada setiap gap, diberikan bobot nilai sesuai dengan tabel berikut:

Tabel 1. Bobot Nilai Gap

\begin{tabular}{cccl}
\hline No & $\begin{array}{c}\text { Selisih } \\
(\text { Gap })\end{array}$ & $\begin{array}{c}\text { Bobot } \\
\text { Nilai }\end{array}$ & \multicolumn{1}{c}{ Keterangan } \\
\hline 1 & 0 & 4 & Tidak ada Gap (kompetensi sesuai yang dibutuhkan) \\
\hline 2 & 1 & 3,5 & Kompetensi individu kelebihan 1 tingkat/level \\
\hline 3 & -1 & 3 & Kompetensi individu kurang 1 tingkat/level \\
\hline 4 & 2 & 2,5 & Kompetensi individu kelebihan 2 tingkat/level \\
\hline 5 & -2 & 2 & Kompetensi individu kurang 2 tingkat/level \\
\hline 6 & 3 & 1,5 & Kompetensi individu kelebihan 3 tingkat/level \\
\hline 7 & -3 & 1 & Kompetensi individu kurang 3 tingkat/level \\
\hline Sumber : Kusrini (2007) & &
\end{tabular}

2. Perhitungan dan Pengelompokan Core dan Secondary Factor

Setelah menentukan bobot nilai gap untuk ketiga aspek yang dibutuhkan, kemudian tiap aspek dikelompokkan lagi menjadi 2 kelompok yaitu core factor dan secondary factor.

a. Core Factor (Faktor Utama)

Core Factor merupakan aspek(kompetensi) yang paling menonjol/ paling dibutuhkan oleh suatu jabatan yang diperkirakan dapat menghasilkan kinerja optimal.

Untuk menghitung core factor digunakan rumus:

$$
\mathrm{NCF}=\frac{\sum \mathrm{NC}}{\sum \mathrm{IC}}
$$

Keterangan :

$\mathrm{NCF}=$ Nilai rata-rata core factor aspek kapasitas intelektual

$\mathrm{NC}=$ Jumlah total nilai core factor aspek kapasitas intelektual

IC = Jumlah item core factor

b. Secondary Factor (Faktor Pendukung)

Secondary Factor adalah item-item selain aspek yang ada pada core factor.

Untuk menghitung secondary factor digunakan rumus:

$$
\mathrm{NSF}=\frac{\sum \mathrm{NS}}{\sum \mathrm{IS}}
$$

Keterangan :

$\mathrm{NSF}=$ Nilai rata-rata secondary factor aspek kapasitas intelektual

$\mathrm{NS}=$ Jumlah total nilai secondary factor aspek kapasitas intelektual 
IS = Jumlah item secondary factor

Rumus diatas adalah rumus untuk menghitung core factor dan secondary factor dari aspek kapasitas intelektual. Rumus diatas juga digunakan untuk menghitung core factor dan secondary factor dari aspek sikap kerja dan perilaku.

3. Perhitungan Nilai Total Tiap Aspek

Dari perhitungan core factor dan secondary factor dari tiap-tiap aspek, kemudian dihitung nilai total dari tiap-tiap aspek yang diperkirakan berpengaruh pada kinerja tiap-tiap profile. Untuk menghitung nilai total dari masing-masing aspek, digunakan rumus:

$$
\mathrm{N}=60 \% \mathrm{NC}+40 \% \mathrm{NS}
$$

Keterangan :

$\mathrm{N}=$ Nilai total tiap aspek

$\mathrm{NCF}=$ Nilai Core Factor

$\mathrm{NSF}=$ Nilai Secondary Factor

4. Perhitungan Rangking

Hasil akhir dari proses profile matching adalah rangking dari kandidat yang diajukan untuk mengisi suatu jabatan/posisi tertentu. Penentuan mengacu rangking pada hasil perhitungan yang ditujukan pada rumus dibawah ini:

\section{Rangking $=20 \%$ NKI $+30 \%$ NSK $+50 \%$ NP}

Keterangan :

$\mathrm{NI}=$ Nilai Kapasitas Intelektual

NSK $=$ Nilai Sikap Kerja

$\mathrm{NP}=$ Nilai Perilaku

Pada penelitian ini, penentuan kriteria yang akan digunakan ditentukan oleh pimpinan (Decision Maker) yang disesuaikan dengan aturan-aturan yang ada pada objek penelitian yang terkait dengan seleksi calon calon Penerima batnuan sapi ternak.

\section{Analisis Sistem Berjalan}

Sistem yang sedang berjalan pada saat ini di desa Buntulia Utara Kabupaten Pohuwato sebagai berikut: 


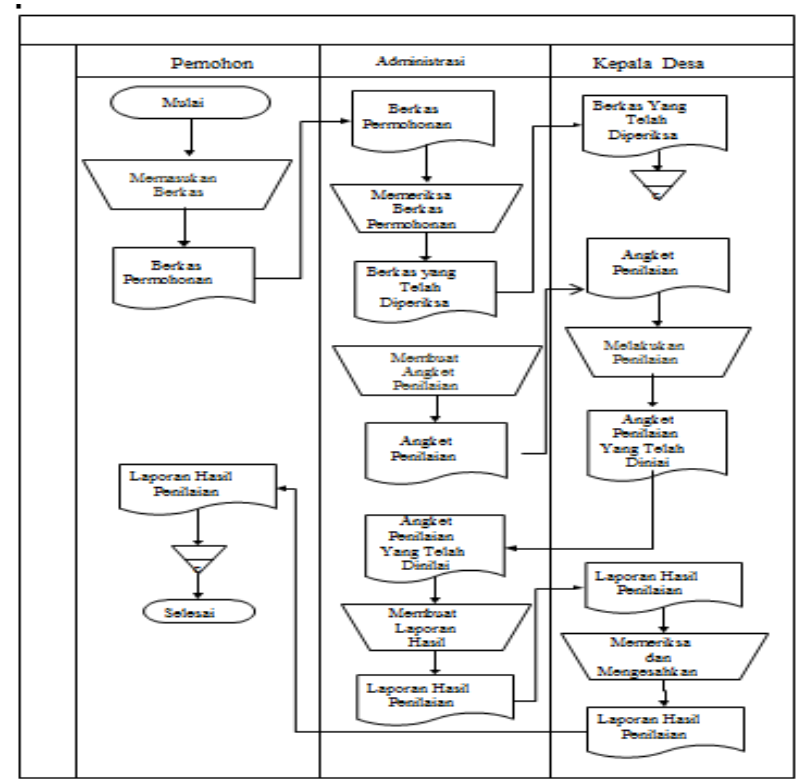

Gambar 1. Sistem yang berjalan

\section{Analisis Sistem yang Diusulkan}

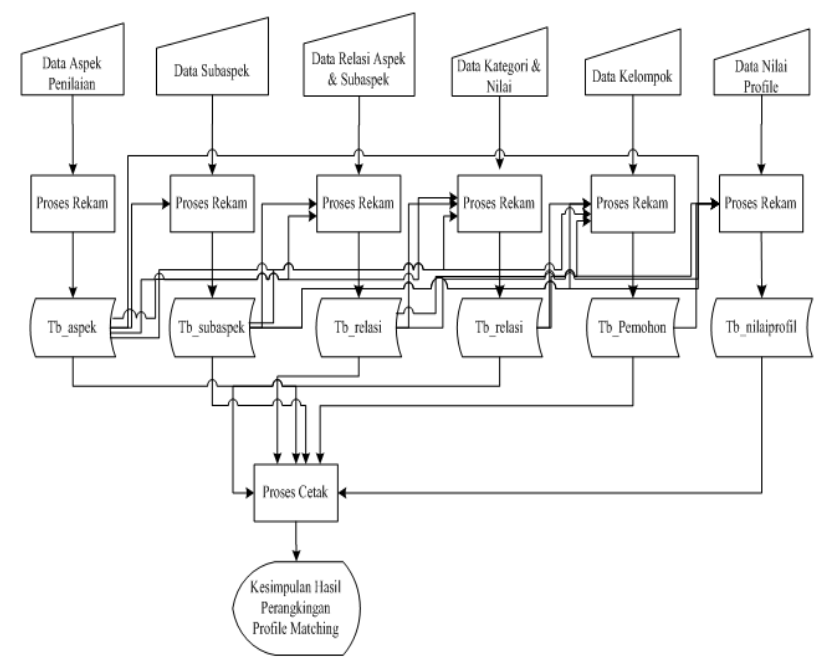

Gambar 2. Sistem yang diusulkan

\section{E. Tahapan Identifikasi Sistem}

1. Mengidentifikasikan masalah

2. Memahami kerja dari sistem yang ada

3. Menganalisis sistem

4. Membuat laporan hasil analisis.

\section{F. Teknik Penelitian}

1. Lokasi Penelitian

Penelitian ini dilaksanakan di Desa Buntulia Utara Kabupaten Pohuwato Provinsi Gorontalo.

2. Metode pengumpulan data

a. Wawancara, merupakan teknik pengumpulan data yang dilakukan melalui tatap 
muka dan tanya jawab langsung antara pengumpul data maupun peneliti terhadap nara sumber atau sumber data.

b. Pengumpulan data dengan observasi langsung atau dengan pengamatan langsung adalah cara pengambilan data dengan menggunakan mata tanpa ada pertolongan alat standar lain untuk keperluan tersebut.

\section{HASIL DAN PEMBAHASAN}

\section{A. Hasil Penelitian}

1. Pengujian White Box

a. Flowchart Data Kelompok

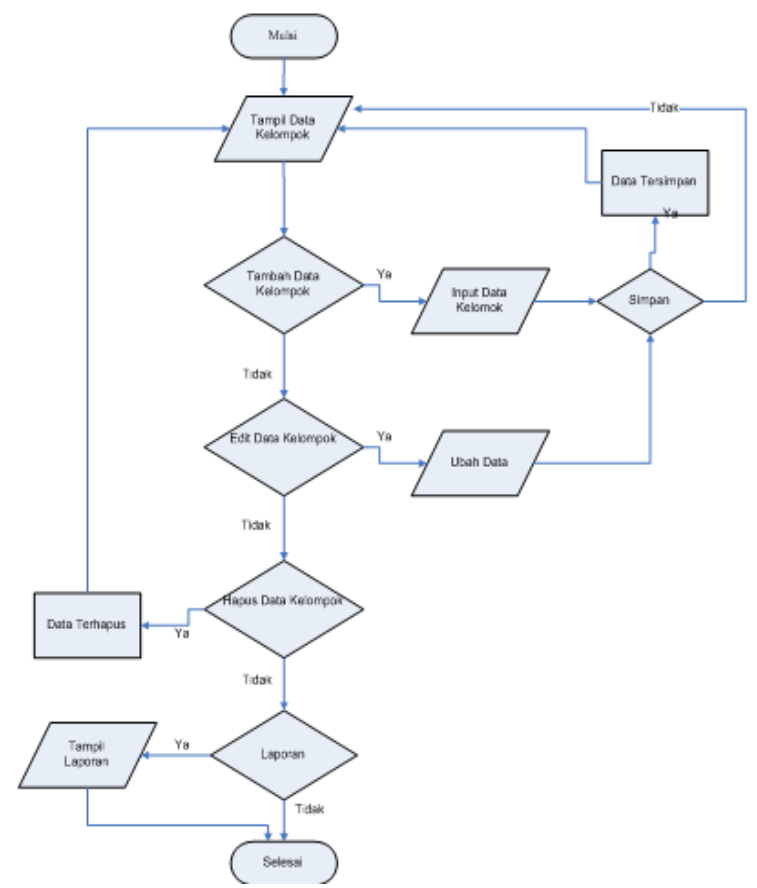

Gambar 3. Flowchart Data Kelompok 
b. Flowgraph

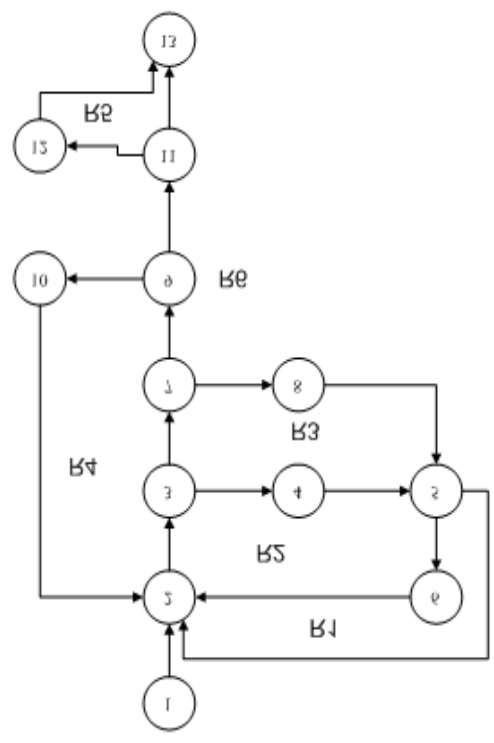

Gambar 4. Flowgraph Data Kelompok

Menghitung Nilai Cyclomatic Complexity (CC)

Dimana :

$\operatorname{Node}(\mathrm{N}) \quad=13$

Edge $(\mathrm{E}) \quad=17$

Predicate Node $(\mathrm{P}) \quad=5$

$\operatorname{Region}(\mathrm{R}) \quad=6$

$\mathrm{V}(\mathrm{G}) \quad=\mathrm{E}-\mathrm{N}+2$

$=17-13+2$

Cyclomatic Complaxity $(\mathrm{CC})=6$

$\mathrm{V}(\mathrm{G}) \quad=\mathrm{P}+1$

$=5+1$

Cyclomatic Complaxity (CC) $=6$

B. Pembahasan

a) Deskripsi Kebutuhan Hardware/Sofware

Penulis dalam mengembangkan Website ini menggunakan bahasa pemrograman PHP (Hypertext Preprocessor) dan Basis Data MySQL. Pada dasarnya, untuk implementasi system ini membutuhkan beberapa konfigurasi dasar, diantaranya.

1. Hardware dan Software

Spesifikasi yang disarankan untuk komputer

a. Processor setara Pentium IV 1.8 Ghz atau lebih

b. RAM (Memory) $256 \mathrm{MB}$ ataulebih

c. HDD $40 \mathrm{~GB}$ ataulebih.

d. Monitor SVGA dengan Resolusi 1024 X 768

e. LAN Card

f. Dan Peralatan I/O Lainnya 
g. Windows XP, Vista atau Windows 7

h. Browser Mozilla Firefox, Internet Explorer dan Opera untuk membuka Web

2. Brainware

Yaitu sumber daya manusia yang terlibat di dalam mengoperasikan serta mengatur sistem komputer. Sumber daya yang dibutuhkan dengan karakteristik sebagai berikut memiliki kemampuan dasar tentang komputer dan proses yang berlangsung di dalamnya.

\section{b) Langkah-langkah menggunakan sistem}

a. Tampilan Halaman Login Admin

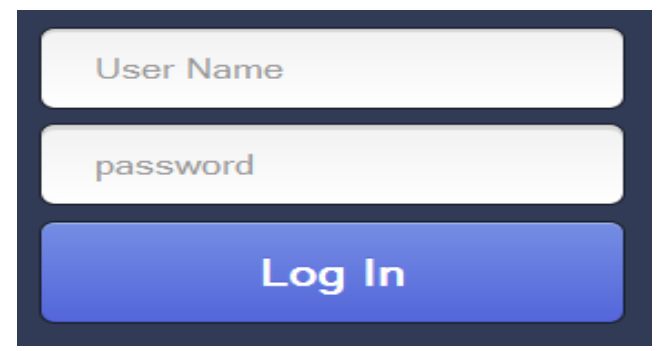

Gambar 5. Tampilan Form Login Admin

b. Tampilan Home Admin

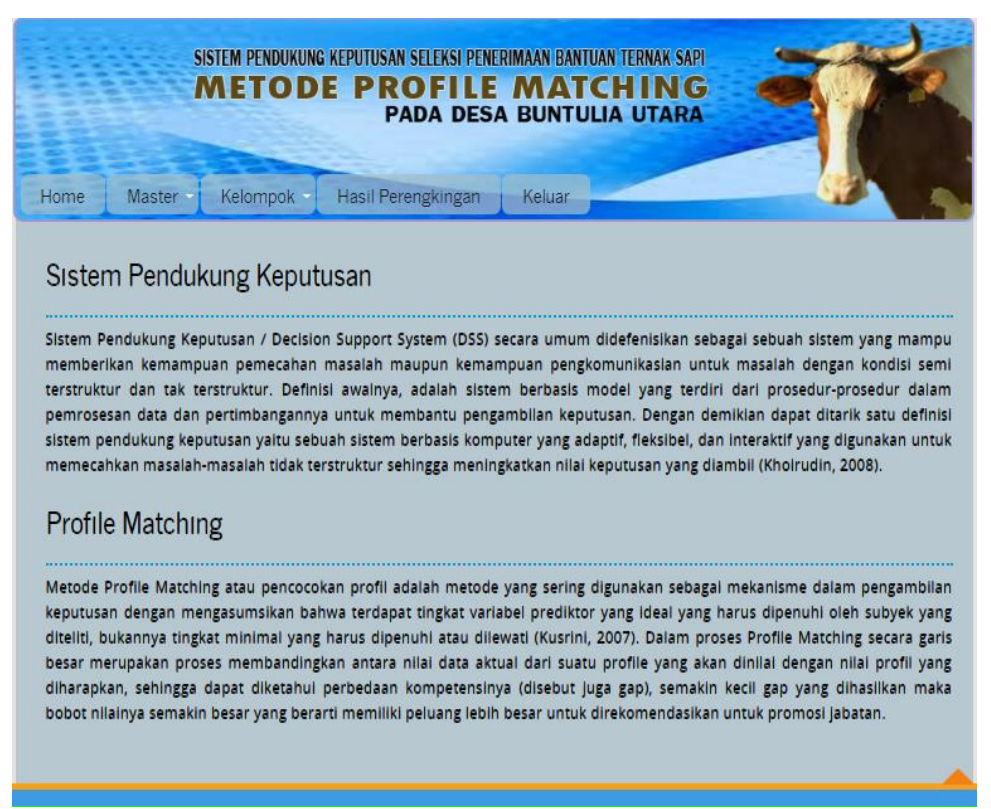

Gambar 6. Tampilan Home Admin 
c. Tampilan Halaman View Data Aspek

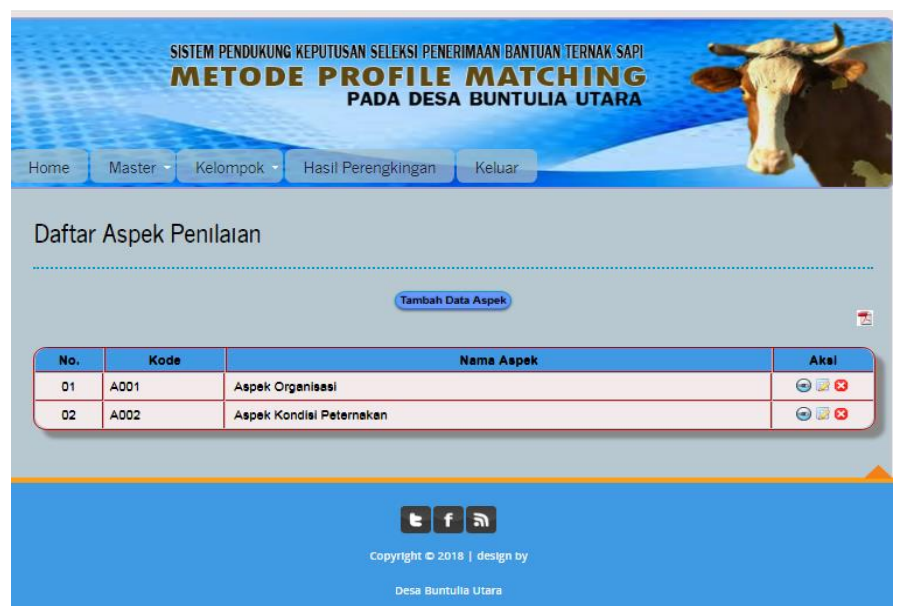

Gambar 7. Tampilan HalamanView Data Aspek

d. Tampilan Form Tambah Data Aspek

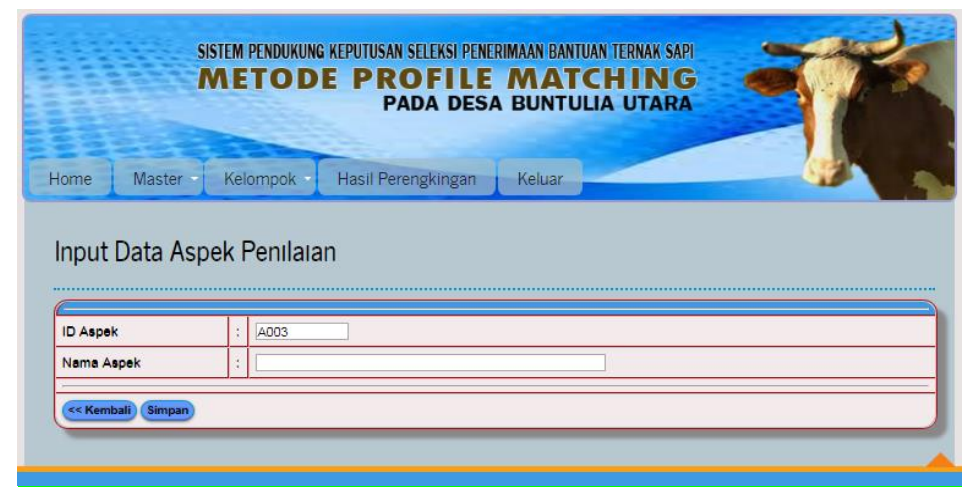

Gambar 8. Tampilan Form TambahData Aspek

e. Tampilan Halaman View Data Subaspek

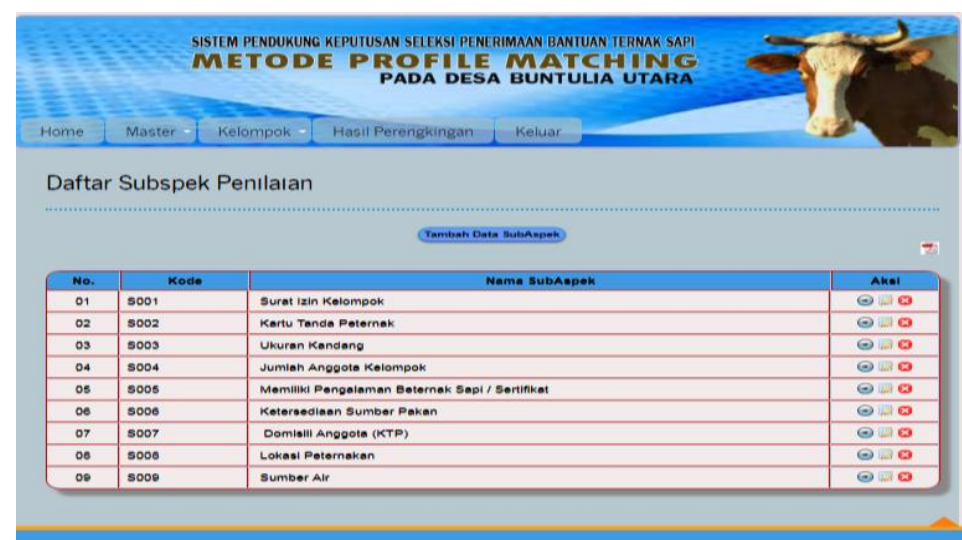

Gambar 9. Tampilan Halaman View Data Subaspek 
f. Tampilan Halaman Relasi Aspek dan Subaspek

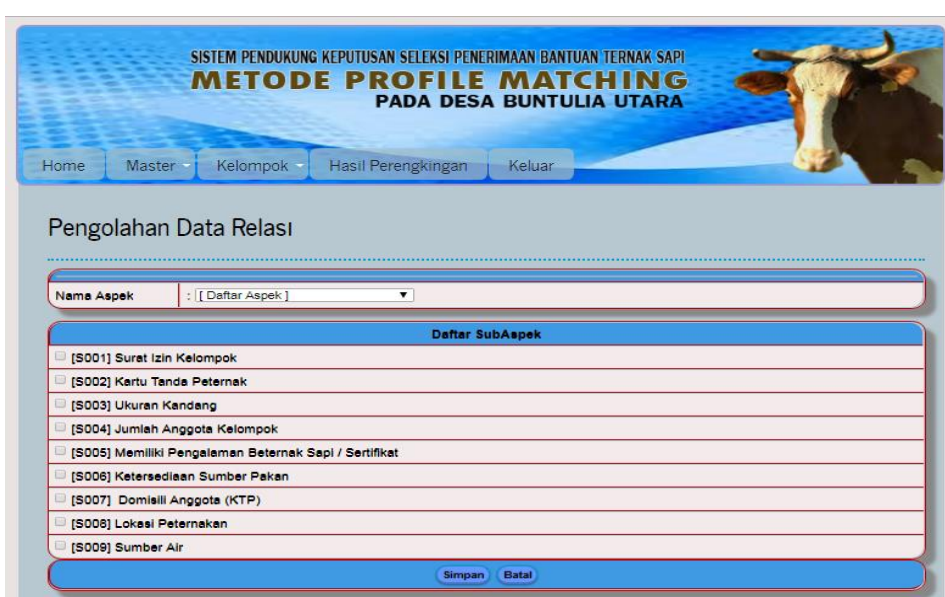

Gambar 10. Tampilan Halaman Relasi Aspek dan Subaspek

g. Tampilan Halaman Relasi Data Kategori \& Nilai

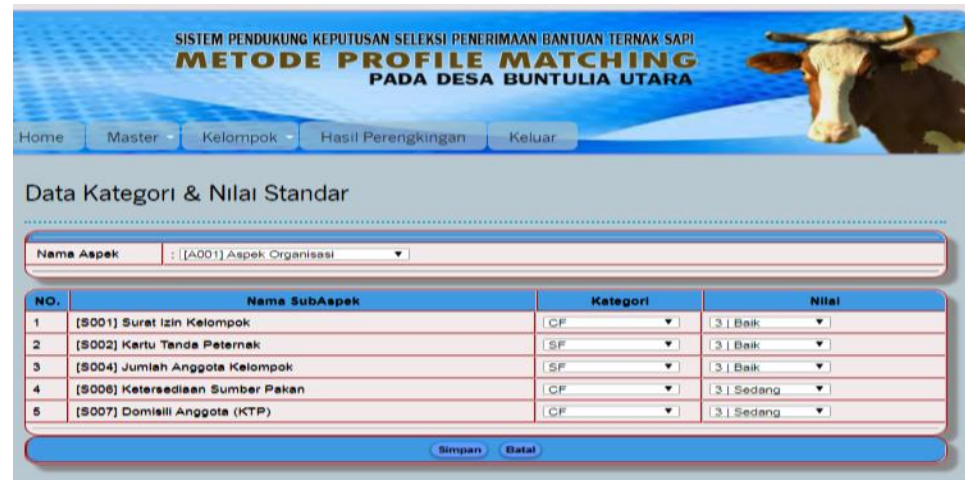

Gambar 11. Tampilan Halaman Data Kategori \& Nilai

h. Tampilan Halaman View Data Kelompok

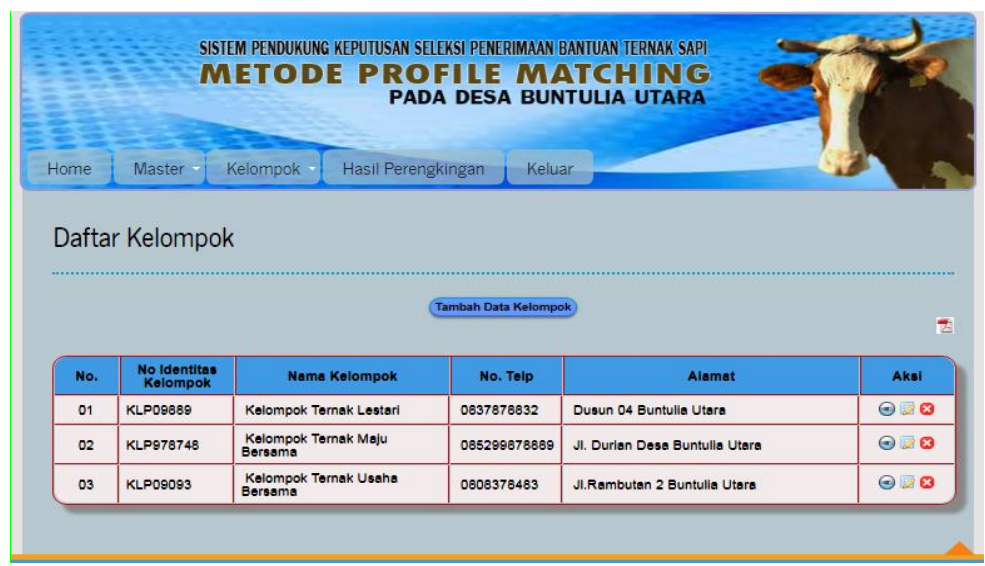

Gambar 12. Tampilan Data Kelompok 
i. Tampilan Halaman Data Nilai Profil Kelompok

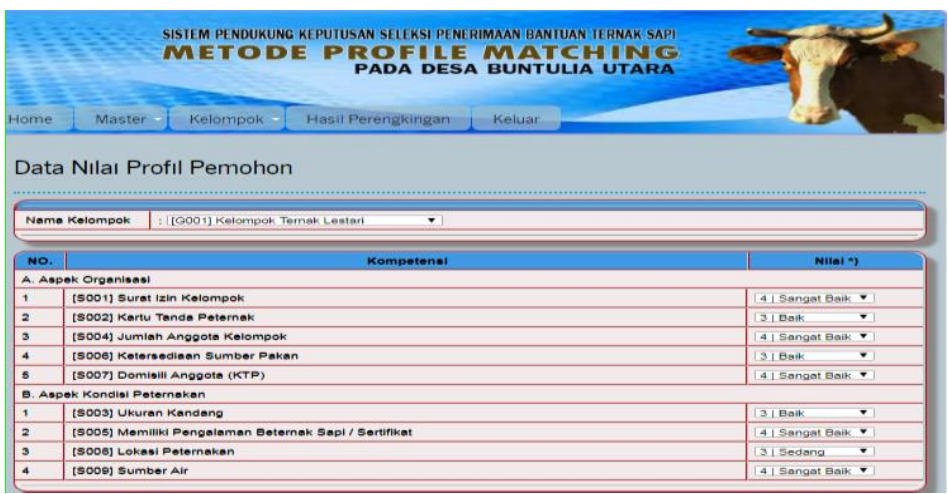

Gambar 13. Tampilan Halaman Data Nilai Profil Kelompok

j. Tampilan Halaman View Hasil Perangkingan

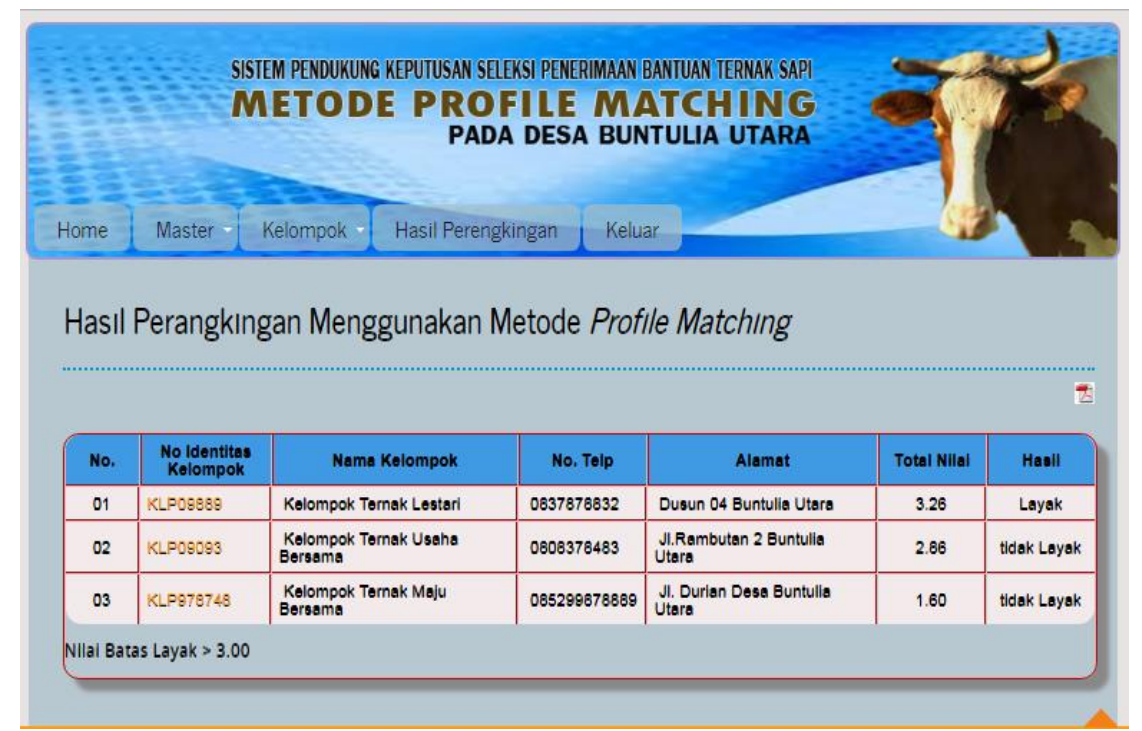

Gambar 14. Tampilan Halaman View Hasil Perangkingan

\section{KESIMPULAN DAN SARAN}

\section{A. Kesimpulan}

Berdasarkan hasil penelitian yang dilakukan pada Kantor Desa Buntulia Utara dan pembahasan yang telah diuraikan sebelumnya, maka dapat ditarik suatu kesimpulan bahwa:

1. Sistem Pendukung Keputusan Penerimaan Bantuan Ternak Sapi Kelompok Meggunakan Metode Profile Matching dapat direkayasa, sehingga membantu dan memudahkan pihak terkait pada Kantor Desa Buntulia Utara dalam menentukan Kelompok yang berprestasi.

2. Dapat diketahui bahwa Sistem Pendukung Keputusan Penerimaan Bantuan Ternak Sapi Meggunakan Metode Profile Matching yang direkayasa dapat digunakan. Hal ini dibuktikan dengan hasil pengujian yang dilakukan dengan metode White Box 
Tesing dan Basis Path yang menghasilkan nilai $\mathrm{V}(\mathrm{G})=6 \mathrm{CC}$ sehingga didapat bahwa logika flowchart benar dan menghasilkan aplikasi Sistem Pendukung Keputusan Penerimaan Bantuan Ternak Sapi yang tepat dan dapat digunakan.

\section{B. Saran}

Setelah melakukan Penelitian dan pembuatan Sistem Pendukung Keputusan Penerimaan Bantuan Ternak Sapi Meggunakan Metode Profile Matching Pada Kantor Kantor Desa Buntulia Utara, ada beberapa saran yang perlu diperhatikan untuk mencapai tujuan yang diharapkan, yaitu sebagai berikut:

1. Diharapkan aplikasi ini masih dapat dikembangkan ke aplikasi berbasis android.

2. Perlu dilakukan bimbingan teknis dalam penggunaan sistem ini yaitu Sistem Pendukung Keputusan Penerimaan Bantuan Ternak Sapi, agar mempermudah pihak Kantor Desa Buntulia Utara Kabupaten Pohuwato dalam penggunaannya.

\section{DAFTAR PUSTAKA}

Jogiyanto, HM. (2005). Analisis \& Desain Sistem Informasi Pendekatan terstruktur teori dan praktek aplikasi bisnis. Yogyakarta: Penerbit Andi.

Kusrini. (2007). Konsep dan Aplikasi Sistem Pendukung Keputusan. Yogyakarta: Penerbit Andi.

Kades. (2018). Bantuan Ternak sapi. Buntulia Utara

Labu. Irfan. (2018). Intreview tentang . Bantuan Ternak Sapi, Desa Buntulia Utara

Uma Sekaran. (2006). Metodologi Penelitian Untuk Bisnis. Jakarta : Salemba Empat. 